\title{
Craniopharyngioma and other cystic epithelial lesions of the sellar region: a review of clinical, imaging, and histopathological relationships
}

\author{
Gabriel Zada, M.D., ${ }^{1}$ Ning Lin, M.D., ${ }^{1}$ Eric OJerholm, B.S.E., ${ }^{1}$ \\ Shakti Ramkissoon, M.D., Ph.D., ${ }^{2}$ and Edward R. Laws, M.D. ${ }^{1}$ \\ Departments of ${ }^{1}$ Neurosurgery and ${ }^{2}$ Pathology, Brigham and Women's Hospital, Harvard Medical School, \\ Boston, Massachusetts
}

\begin{abstract}
Object. Cystic epithelial masses of the sellar and parasellar region may be difficult to differentiate on a clinical, imaging, or even histopathological basis. The authors review the developmental relationships and differentiating features of various epithelial lesions of the sellar region.

Methods. The authors performed a review of the literature to identify previous studies describing the etiological relationships and differentiating features of various cystic sellar lesions, including craniopharyngioma (CP), Rathke cleft cyst, xanthogranuloma, and dermoid and epidermoid cysts.

Results. There is significant evidence in the literature to support a common ectodermal origin of selected sellar and suprasellar cystic lesions, which may account for the overlap of features and transitional states observed in some cases. Research obtained from animal studies and reports of transitional cystic epithelial masses or lesions crossing over from typical to more aggressive pathological subtypes have collectively provided a solid foundation for this theory. Histological features that signify transitional entities beyond simple benign Rathke cleft cysts include squamous metaplasia, stratified squamous epithelium, and ciliated or mucinous goblet cells in squamous-papillary CPs. Several studies have identified key clinical, imaging, and histopathological features that can be used in the differentiation of these lesions.

Conclusions. The pattern of embryological formation of the hypothalamic-pituitary axis plays a major role in its propensity for developing cystic epithelial lesions. Subsequent inflammatory, metaplastic, and neoplastic processes may promote further progression along the pathological continuum, ranging from benign epithelial cysts to aggressive neoplastic cystic CPs. Selected clinical, imaging, and histopathological features can be used collectively to help differentiate these lesions and assign a formal diagnosis, thus accurately guiding further treatment. (DOI: 10.3171/2010.2.FOCUS09318)
\end{abstract}
KEY WORDS
- craniopharyngioma embryology $\quad$ magnetic resonance imaging embryology - magnetic resonance imaging
Rathke cleft cyst
- epithelial cyst •

$\mathrm{D}$ IFFERENTIATION of cystic lesions of the sellar and parasellar region may pose a diagnostic dilemma to neurosurgeons, radiologists, and pathologists involved in treating patients with these entities. As a result of the pattern of embryological development of the adenohypophysis from its stomodeal origin, as well as subsequent inflammatory, metaplastic, and neoplastic processes that can occur, the potential exists for the formation of a variety of cystic lesions in the sellar and parasellar region. The spectrum of cystic pathology occurring in the sellar region includes CPs, RCCs, colloid cysts, arachnoid cysts, cystic pituitary adenomas, xanthogranulomas, epidermoid cysts, dermoid cysts, and several others. ${ }^{15,60}$ In the majority of cases, a straightforward diag-

\footnotetext{
Abbreviations used in this paper: $\mathrm{CP}=$ craniopharyngioma: $\mathrm{RCC}=$ Rathke cleft cyst.
}

nosis of typical cystic lesions is established with little difficulty based on the lesion's clinical, imaging, and histopathological characteristics. In some cases, however, a significant degree of overlap in these features occurs and may preclude the assignment of a definitive diagnosis. Establishing an accurate working diagnosis for sellar region pathology is critical in formulating appropriate surgical goals, predicting the likelihood of lesion recurrence, and guiding postoperative adjunctive management.

In 1994, Harrison and colleagues ${ }^{34}$ reported 19 cases of cystic epithelial lesions, in which overlapping radiological and histopathological features were evident in almost half, rendering 3 lesions without a formal diagnosis. Their study, in addition to several others, posited that cystic epithelial lesions may comprise varying entities along a continuum of pathology derived from a common ectodermal origin in the primitive craniopharyngeal duct, 
thus accounting for the overlapping features observed in selected lesions. ${ }^{2,25,30,32,34,69,70,113}$ At one end of this pathological spectrum are benign RCCs, which are nonneoplastic lesions generally accepted to be derived from the remnant of the Rathke pouch. At the other end are CPs, which are neoplastic, often aggressive lesions thought to arise from squamous epithelial cell rests occurring anywhere along the region of the primitive stomodeum, from the sella to the infundibulum to the tuber cinereum and floor of the third ventricle.

In this summary, a current analysis of the developmental and clinicopathological relationships among CPs, RCCs, and other cystic epithelial derivatives of the sellar region is provided. The embryological development of the hypothalamic-pituitary region and various reasons for its particular predisposition to developing a variety of cystic lesions is discussed. Furthermore, we review the evidence favoring a common ectodermal origin, in contrast to alternative nonectodermal hypotheses, for the origin of cystic epithelial lesions. Finally, we review the typical and atypical features of RCCs and CPs, as well as the clinical, imaging, and histopathological features that have proved to be most useful in differentiating these lesions.

\section{Craniopharyngiomas: Typical Features}

Craniopharyngiomas can arise anywhere along the vestiges of the stomodeal diverticulum, but they most frequently originate in the region of the infundibulum, where squamous epithelial rests are known to occur. ${ }^{49,52,84}$ In rare cases, CPs arise in less typical locations along the remnants of the primitive craniopharyngeal duct, including the nasopharynx, sphenoid bone, or as primary intraventricular lesions. ${ }^{11,20,46,49}$ Overall, CPs comprise approximately $3 \%$ of all intracranial tumors, yet this proportion is notably higher in the pediatric population $(10 \%$ of all pediatric brain tumors). ${ }^{23,48,49,51}$ The estimated incidence of craniopharyngiomas is 0.13 per 100,000 cases per year. ${ }^{12}$ Historically, CPs present in a bimodal age distribution with peak ages at the time of presentation of 5-14 years and then 50-74 years. ${ }^{12}$ However, these lesions may present in patients of all ages. The clinical presentation of CPs at any age frequently includes headache, vision loss, and hypopituitarism. ${ }^{16,52}$ In children, growth and sexual retardation, obesity, and hydrocephalus are frequently observed as well. ${ }^{51,59}$ Many patients with CPs suffer from chronic obesity, which is thought to develop secondary to hypothalamic dysfunction. Memory loss and cognitive deficits are more common findings in older patients. ${ }^{37}$ Diabetes insipidus is seen on presentation in $6-38 \%$ of new cases. ${ }^{38,52}$

The 2 major pathological subtypes of $\mathrm{CP}$ are the adamantinomatous and squamous-papillary varieties, although mixed-type lesions have been reported. ${ }^{20,22}$ These 2 generalized tumor subtypes vary in age at presentation, tumor location, consistency, imaging characteristics, and histopathological features. ${ }^{1,92,109}$

\section{Typical Imaging Features of CP}

From an imaging standpoint, CPs are typically described as calcified, solid, and/or cystic lesions, typically

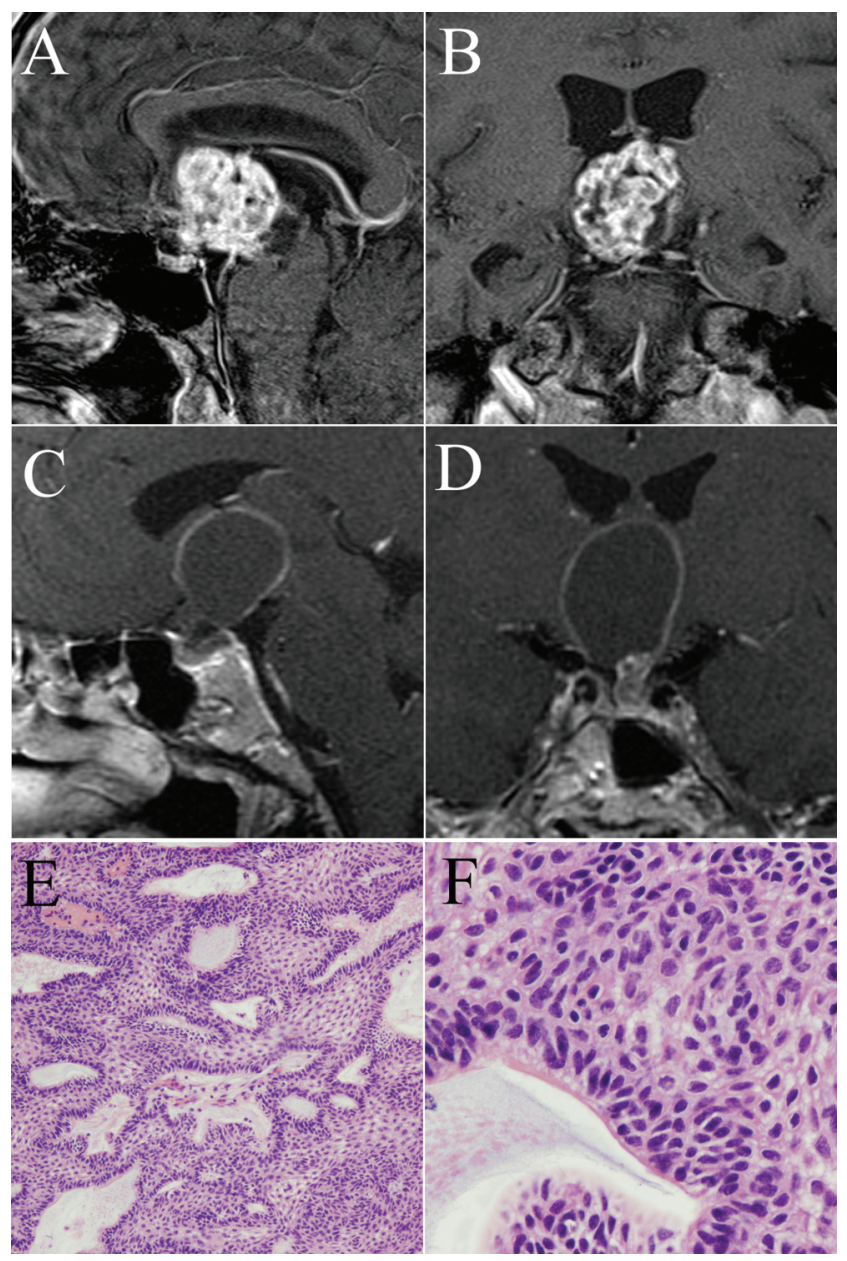

Fig. 1. Imaging and histopathological examples of typical adamantinomatous craniopharyngiomas. A and B: Sagittal and coronal Gdenhanced MR images obtained in a patient with a primarily solid suprasellar craniopharyngioma. C and D: Coronal Gd-enhanced MR images acquired in a patient with a mixed solid and cystic suprasellar craniopharyngioma. E and F: Photomicrographs of typical adamantinomatous craniopharyngioma composed of squamous epithelium arranged in sheets, lobules, and anastomosing trabeculae lined by palisaded columnar epithelium. $\mathrm{H} \& \mathrm{E}$, original magnification $\times 100$ (E) and $400(F)$.

with a lobular shape and diameter of $20-40 \mathrm{~mm}$ (Fig. 1). ${ }^{1,26,109}$ The majority of CPs involve the suprasellar space, with $40-53 \%$ of cases exhibiting some intrasellar involvement. ${ }^{51,105}$ Craniopharyngiomas occasionally extend into the anterior, middle, or posterior fossa and may invade the floor or walls of the third ventricle. ${ }^{26,105}$ Hydrocephalus is observed in up to $38 \%$ of cases and is a more common finding in children. ${ }^{51,109}$

On standard CT scanning, calcification is evident in $60 \%$ of tumors and is more common in pediatric cases and the adamantinomatous subtype.,52,92,109 The majority of adamantinomatous CPs are mixed solid-cystic or predominantly cystic tumors with a lobulated appearance (Fig. 1)., ${ }^{192,109}$ On MR imaging, the solid elements are usually iso- or hypointense on T1-weighted images, exhibit inhomogeneous high intensity on T2-weighted images, and heterogeneously enhance following Gd administra- 

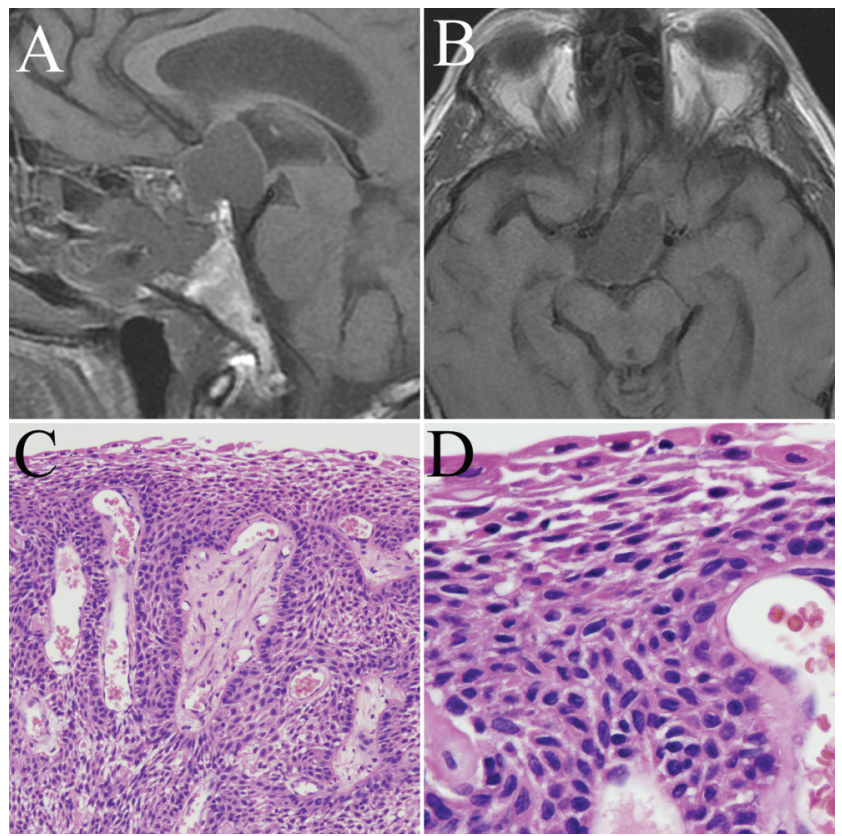

FIG. 2. Imaging and histopathological examples of papillary CP. A and B: Sagittal and axial MR images. C and D: Photomicrographs of typical papillary CP composed of well-differentiated squamous epithelium supported by a network of fibrovascular cores. $\mathrm{H}$ \& E, original magnification $\times 100$ (C) and 400 (D).

tion. ${ }^{17,92}$ The cystic elements of adamantinomatous CPs typically display a high intensity on T1-weighted images, high or mixed intensity on T2-weighted images, and contrast enhancement of the cyst wall..$^{92}$ The squamouspapillary subtype is found in approximately one-third of adult $\mathrm{CP}$ cases and rarely shows calcification. ${ }^{1,20,92,109}$ The majority of squamous-papillary CPs are predominantly solid or mixed solid-cystic tumors with a spherical shape, and usually exhibit low intensity on T1-weighted images, high intensity on T2-weighted images, and enhancement of the cyst wall after addition of Gd (Fig. 2).,20,92 The MR imaging appearance of the solid regions is frequently similar to those of the adamantinomatous variety.

\section{Typical Histopathological Features of CP}

Histologically, adamantinomatous CPs are thought to arise from squamous embryonic rests and bear similarity to adamantinomas or ameloblastomas of the jaw with the potential for enamel production (Fig. 1). The epithelium is often stratified squamous or adamantinoid type, frequently with evidence of wet keratin nodules. The cystic components are often described as having a characteristic "machine-oil" interior, containing desquamated squamous epithelium and comprised mainly of keratin and cholesterol.

The papillary subtype of $\mathrm{CP}$ is known to occur more commonly in adults than children (14-50\% of craniopharyngioma in adults compared with only $2 \%$ of $\mathrm{CP}$ in children). ${ }^{20}$ Papillary CPs usually bear similarity to oropharyngeal mucosa and rarely exhibit calcification. The cyst contents are typically yellow and viscous. Histopathological analysis frequently demonstrates squamous
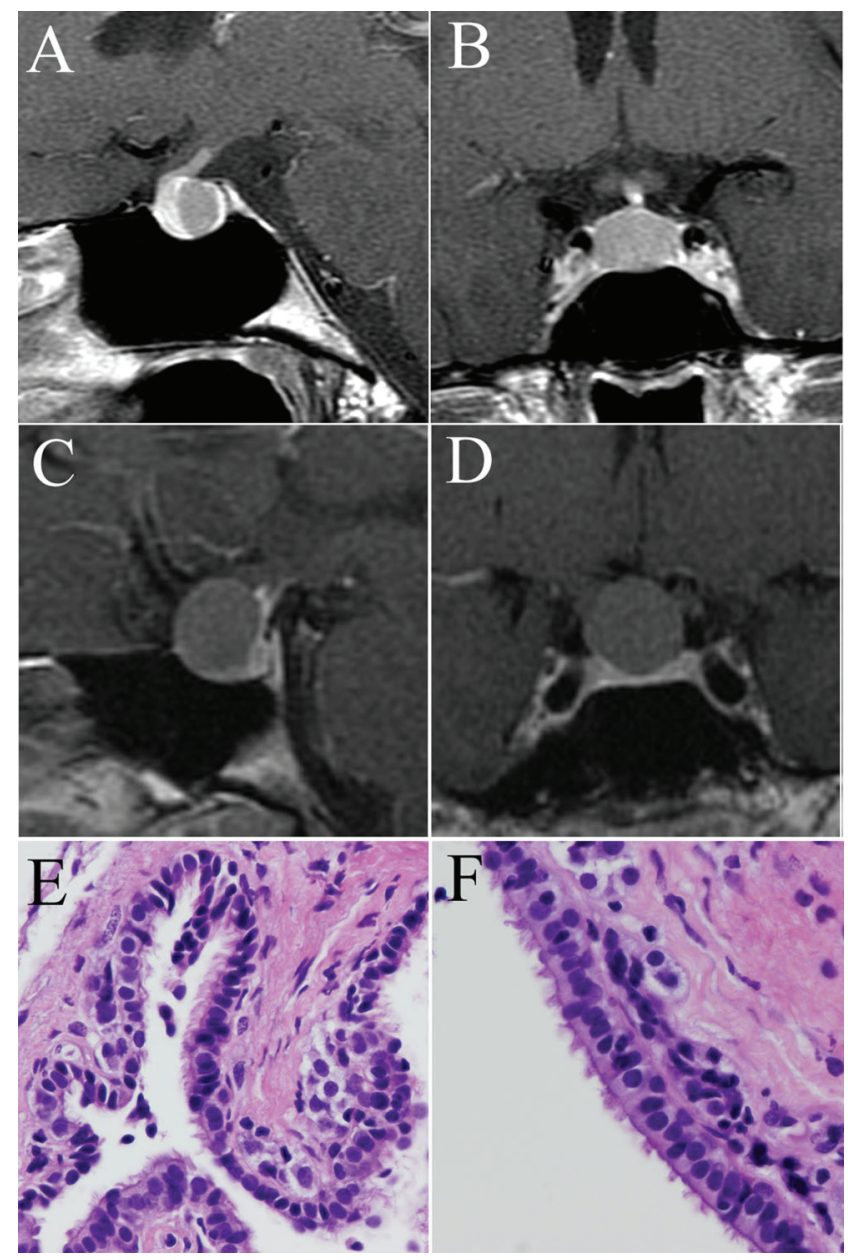

FIG. 3. Imaging and histopathological examples of typical RCCs. A and B: Sagittal and coronal Gd-enhanced MR images obtained in a patient with an intrasellar RCC located between the anterior and posterior pituitary gland. C and D: Sagittal and coronal Gd-enhanced MR images obtained in a patient with an intra- and suprasellar RCC. E and F: Photomicrographs of typical RCC lined by a single layer of columnar, ciliated epithelium. $H$ \& E, original magnification $\times 100(E)$ and $400(F)$

epithelium forming pseudopapillae, without discrete nodules of wet keratin or calcium. There has been some debate as to whether adamantinomatous CPs demonstrate a higher potential for recurrence, although recent analyses have reported similar or slightly higher rates than their papillary counterparts. ${ }^{1,20,109}$ Several investigators have argued that papillary and adamantinomatous CPs may also represent 2 distinct entities that are located at opposing ends of a pathological continuum. ${ }^{22,109}$ It has been reported that various markers, including KL-1 or cytokeratin 7, can be used to distinguish the adamantinomatous and papillary varieties of CP.58

\section{Rathke Cleft Cysts: Typical Features}

Rathke cleft cysts are benign, cystic remnants of the craniopharyngeal duct that are typically located in the sellar and suprasellar region. ${ }^{19,50}$ They are often discovered incidentally and have been identified in up to $22 \%$ of the population according to routine examination of 
autopsy specimens. ${ }^{100}$ Despite their relatively high prevalence, they result in clinical symptoms in a minority of patients, comprising only 5-9\% of all surgically resected sellar lesions. ${ }^{2,56,108,115,116}$ Typical symptoms associated with RCCs include headache, endocrine dysfunction, and visual loss. ${ }^{2,45}$ Less frequently, RCCs can present with chemical meningitis, abscess, lymphocytic hypophysitis, or intracystic hemorrhage and apoplexy. ${ }^{56,96}$ Although the peak age at the time of clinical presentation is generally 40-50 years, ${ }^{2,7,56}$ RCCs can also cause symptoms in children, potentially resulting in somatic and/or sexual retardation in addition to the more common symptoms described above. ${ }^{114}$

\section{Typical Imaging Features of RCCs}

On MR imaging, RCCs often appear as well-circumscribed, centrally located spherical or ovoid lesions of the sellar region. The majority of these smooth contoured cysts are unilobar with a diameter ranging between 5-40 mm (mean approximately $17 \mathrm{~mm}$ ) (Fig. 3). ${ }^{56,75,97}$ They are often identified as having an epicenter located between the anterior and posterior pituitary gland in the region of the pars intermedia. The vast majority of lesions are intrasellar or intra- and suprasellar, with reports of purely suprasellar lesions occurring in a minority of patients. ${ }^{6,110}$ The normal pituitary gland may be displaced in any direction by an RCC, including circumferentially if the cyst arises in and remains encased within the gland. ${ }^{10,86}$

In the majority of cases, administration of Gd contrast material demonstrates little or no enhancement of the cyst wall or contents on MR imaging., ${ }^{7,14}$ A thin peripheral rim of enhancement has been attributed to inflammation or squamous metaplasia of the cyst wall, or to a circumferential rim of displaced pituitary gland. ${ }^{10,56}$ The MR imaging signal intensity of cyst contents demonstrates high variability on T1- and T2-weighted sequences and has been reported to correlate with the nature of the cystic contents..$^{4,35,102}$ In the series by Kim et al., ${ }^{56}$ the 3 most common signal patterns were a high intensity on both T1and T2-weighted images, a low intensity on T1-weighted images with a high intensity on T2-weighted images, and a high intensity on T1-weighted images with a low intensity on T2-weighted images. Rathke cleft cysts filled with thin, CSF-like fluid generally exhibit a low intensity on T1-weighted images and a high intensity on T2-weighted images, while cysts with more proteinaceous, mucoid fluid correlate with higher intensity on T1-weighted images..$^{10,17,35,90}$ Although most RCCs display a homogeneous signal intensity, up to $40 \%$ contain a waxy intracystic nodule composed of protein and cellular debris that typically fails to enhance following contrast administration. . $^{8,10,14}$

\section{Typical Histopathological Features of RCCs}

Histopathologically, RCCs typically demonstrate simple columnar or cuboidal epithelium, often with ciliated or mucinous goblet cells (Fig. 3). Pseudostratified columnar cells are also commonly observed in specimens of RCCs. Squamous metaplasia of RCCs has been noted in $9-39 \%$ of patients and is associated with higher rates of cyst recurrence. ${ }^{2,56,63}$ Similarly, stratified squamous ep- ithelium occurs in a minority of RCCs and is thought to pose a higher risk for cyst recurrence. ${ }^{56}$

There is a tendency for RCCs to develop attachment to the pituitary stalk, which plays a major in the development of postoperative diabetes insipidus and pituitary insufficiency following complete cyst removal.50,61,73 Overall long-term recurrence rates following RCC fenestration or resection have varied from $3-33 \%$ and have been reported to correlate with several factors, including the radiological enhancement pattern of the cyst wall, the presence of squamous metaplasia or stratified epithelium, the aggressiveness of cyst wall resection, and the placement of an abdominal fat graft. . $^{, 754,56,71}$

\section{Epidermoid Cysts: Typical Features}

Epidermoid lesions can occur anywhere in the intracranial cavity. They most commonly arise as extradural lesions or as intracerebral masses in the region of the cerebellopontine angle, but they may also present in the sellar and parasellar region. 9,40,76,91,99,107 Epidermoid cysts often arise in a paramedian location, in contrast to typically midline dermoid cysts. ${ }^{91}$ Sellar and parasellar epidermoid tumors make up only $0.2-0.7 \%$ of major transsphenoidal series. ${ }^{27,89}$ Epidermoid tumors typically present in middle-aged patients with symptoms of mass effect, such as headache and vision loss..$^{31,74,112}$ Some reports have also described an uncommon clinical presentation mimicking that of pituitary apoplexy. ${ }^{91,104}$ The cyst contents of epidermoid cysts, and many other epithelial sellar region cysts, can be caustic to the surrounding tissue, often resulting in hypophysitis, meningitis, or neurological deficits. Standard MR imaging cannot be reliably used in all cases to definitively establish a diagnosis of epidermoid or dermoid tumors, on account of their nonspecific MR imaging features. Demonstration of restricted diffusion on diffusion weighted imaging, however, has been shown to play a useful role in allowing the differentiation of epidermoid lesions from other types of cystic pathology, in particular arachnoid cysts. ${ }^{103}$

Intraoperatively, epidermoid cysts can often be adhesive lesions not universally amenable to a gross-total resection. The cyst capsule and contents cannot consistently be dissected away from key vascular and nervous structures to achieve an acceptable outcome with minimal morbidity. Histologically, epidermoid cysts are characterized by a squamous epithelium, keratohyaline granule layers, and stratifications of "dry" keratin (Fig. 4). Gross-total resection of intradural epidermoid tumors has been reported in $42 \%$ of cases, with a long-term recurrence rate of $26 \% .{ }^{31}$ Resection remains the most effective modality, as no adjunctive measures have been proven to be of significant benefit in the management of these lesions.

\section{Embryologic Development and Origins of Cystic Epithelial Lesions of the Sellar Region}

Elucidation of the developmental processes accounting for the formation of the hypothalamic-pituitary system and related cystic lesions occurred as a result of several investigators over the course of several decades. ${ }^{67}$ Martin 


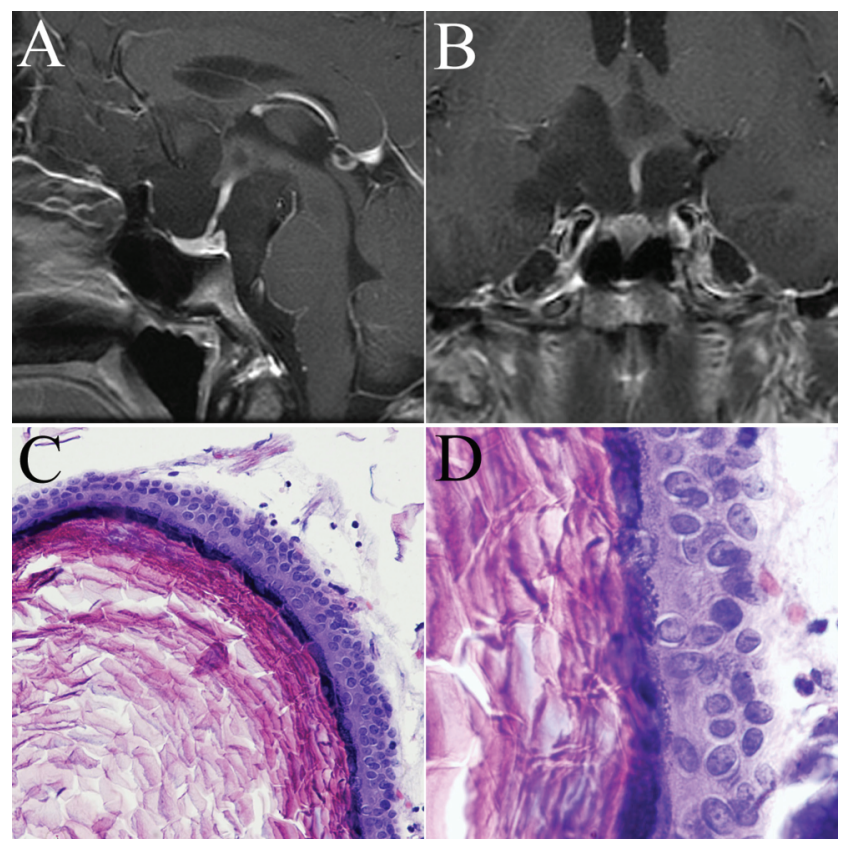

FIG. 4. Imaging and histopathological examples of a suprasellar epidermoid tumor. A and B: Sagittal and coronal Gd-enhanced MR images. $\quad$ C and D: Photomicrographs of typical epidermoid cyst lining composed of keratinizing stratified squamous epithelium with germinal, granular, and corneal layers with abundant acellular keratin debris. Dermal appendages are not present. $\mathrm{H} \& \mathrm{E}$, original magnification $\times 100$ (C) and 400 (D).

Rathke ${ }^{85}$ was the first to describe the evagination process of the anterior foregut in 1838. In 1860, Huber von Luschka ${ }^{66}$ was the first to describe the presence of squamous epithelial rests occurring along the axis of the pituitary gland and infundibulum. Although Babinksi ${ }^{5}$ and Frohlich ${ }^{28}$ each described epithelial suprasellar tumors at around the turn of the century, Jakob Erdheim ${ }^{24}$ first indicated that these lesions, which we now refer to as craniopharyngiomas, arise from squamous cell rests occurring in the region of the remnant hypophyseal/pharyngeal duct.

\section{Embryological Development of the Hypothalamic-Pituitary} Region

The pituitary gland can be divided into 2 distinct anatomical compartments with different ectodermal origins. The adenohypophysis is ultimately formed by an ectodermal outpouching of the stomodeum (primitive oral cavity) located immediately anterior to the oropharyngeal membrane, known as the Rathke pouch. The neurohypophysis, on the other hand, develops from a downward extension of neuroectodermal tissue originating from the diencephalon, called the infundibulum. ${ }^{49,62,88}$

The onset of neurulation begins with the primitive streak and node, which first appear on the dorsal aspect of the embryonic disc at approximately the 3rd week of gestational life. Once the neural tube is formed, transverse segmentation occurs at the midbrain, pons, and cervical levels, and a series of evaginations of the neural tube walls eventually produces several important structures in the CNS. The Rathke pouch (also known as the hypophy- sial diverticulum at this stage) is first noted to appear as an outpouching from the roof of the oral cavity at the 4th week of gestation. During the following weeks, this diverticulum gradually elongates and becomes constricted at its attachment site to the oral epithelium. At 6-8 weeks of life, the pouch loses its connection with the oral cavity and has grown in close contact with the infundibulum dorsally. Between the 3rd and 5th months of gestation, cells in the anterior wall of the Rathke pouch proliferate rapidly to form the pars anterior, whereas cells in the posterior wall do not divide significantly to form abundant glandular tissue. Instead, cells from this less active posterior wall form the pars intermedia, which is frequently not a prominent structure in the adult pituitary gland. Meanwhile, the infundibulum gives rise to the median eminence, the pituitary stalk, and the pars nervosa, or the posterior lobe of the pituitary gland. A small extension of the pars anterior, known as the pars tuberalis, extends superoventrally along the stalk and eventually surrounds it by the 16th week of gestation.

The extensive proliferation of the anterior wall of the hypophysial diverticulum eventually reduces its lumen size to that of a narrow cleft that is not typically recognizable in the adult pituitary. It is likely that CPs, RCCs, and other cystic epithelial lesions originate from remnants of this ectodermal cleft and the associated derivatives of the primitive stomodeum, where squamous cell rests are known to reside. In the past, 2 generalized theories have been proposed to explain the origins of CPs in this region. The "embryogenic theory" states that when the Rathke pouch is detached from the oral epithelium, remnants of ectopic craniopharyngeal duct may be deposited within the sellar region. The craniopharyngeal duct contains ectoblastic cells, which are derived from parts of the stomodeum and could be the origin of adamantinomatous craniopharyngiomas. ${ }^{24,29,80}$ The "metaplastic theory," on the other hand, proposes that squamous epithelial cell rests that are found in the adenohypophysis and infundibulum can undergo metaplasia, thus giving rise to the papillary subtype of CP tumors. ${ }^{80,84,93}$ Evidence supporting and refuting the various theories for both ectodermal and nonectodermal origins of cystic epithelial lesions is further discussed below. It is certainly possible that developmental as well as subsequent metaplastic and neoplastic processes can each play a role in the formation of various lesions along a spectrum of related pathology.

\section{Evidence Lending Support to a Common Ectodermal Origin of Cystic Epithelial Lesions}

The evidence lending support to the prevailing theory of a common ectodermal origin for many cystic epithelial lesions of the sellar region is derived from several sources. These sources include animal laboratory investigations, observational reports of transitional lesions containing features of multiple histopathological lesions, and case reports of progression from one lesion type to another, all of which have provided a credible basis for this viewpoint.

In a study by VanGilder and Inukai ${ }^{106}$ in 1973, oral mucosa was transplanted into the brains of 50 baby rats. The transplanted cells differentiated into a spectrum of 
TABLE 1: Histological characteristics, incidence, and recurrence rates of various cystic epithelial lesions and their subtypes*

\begin{tabular}{|c|c|c|c|}
\hline Lesion Type & Pathological Features & Incidence & $\begin{array}{l}\text { Recurrence } \\
\text { Rate }\end{array}$ \\
\hline \multicolumn{4}{|l|}{$\mathrm{RCC}$} \\
\hline \multirow[t]{2}{*}{ typical $2,7,56,97$} & simple cuboidal or columnar cells & $28-54 \%$ of RCCs & $3-19 \%$ \\
\hline & pseudostratified columnar & $23-49 \%$ of RCCs & $3-19 \%$ \\
\hline $\begin{array}{l}\text { "transitional"2,7,41,56,63,68, } \\
69,91,108,113\end{array}$ & $\begin{array}{l}\text { squamous epithelium, including squamous metaplasia; chronic } \\
\text { inflammation }\end{array}$ & $9-39 \%$ of RCCs & $32-39 \%$ \\
\hline \multicolumn{4}{|l|}{$\mathrm{CP}$} \\
\hline $\begin{array}{l}\text { ciliated or goblet } \\
\quad \text { papillary }{ }^{30,70,77-79,97}\end{array}$ & ciliated or mucinous goblet cells & infrequent case reports & unknown \\
\hline squamous-papillary $1,20,109$ & stratified squamous epithelium, pseudopapillae & $28-33 \%$ in adults, $2 \%$ in children & $0-12 \%$ \\
\hline adamantinomatous $\mathbf{s}^{1,26,109}$ & adamantoid epithelium, wet keratin & $66-68 \%$ in adults, $96-100 \%$ in children & $13-22 \%$ \\
\hline xanthogranuloma ${ }^{63,83}$ & $\begin{array}{l}\text { xanthogranulomatous component, little epithelium (usually } \\
\text { squamous) }\end{array}$ & $34 \%$ of suspected CPs & unknown \\
\hline epidermoid cyst ${ }^{20,31,112}$ & squamous epithelium, dry keratin, keratohyaline granules & $<1 \%$ of primary CNS lesions & $0-26 \%$ \\
\hline
\end{tabular}

* Superscripted numbers indicate studies discussing the respective lesion.

histopathological subtypes characterized by stratified squamous, cuboidal, and transitional epithelium as well as cholesterol clefts, calcification, and bone. The authors concluded that similar progenitor cells may differentiate into the spectrum of cystic epithelial lesions observed in the developing human brain. In another study, Iwata et al. ${ }^{47}$ performed a microscopic analysis of the hypophysis in rats. The authors found evidence of epithelial craniopharyngeal derivatives in approximately $0.16 \%$ of rats, and they suggested developmental rather than neoplastic origins of RCCs and related cystic epithelial lesions. Similarly, Schaetti and colleagues ${ }^{94}$ examined pituitary specimens in rats and reported finding epithelial craniopharyngeal derivatives consisting of cuboidal or columnar epithelium with goblet cells or stratified squamous epithelium. The authors of this study supported a heterotopic, nonneoplastic origin for many of these various epithelial cystic masses as well.

Several varieties of "transitional" or "crossover" cystic epithelial lesions with nonspecific features have been reported in the literature, collectively providing additional support for a theory of sequential progression in epithelial cystic lesions (Table 1). ${ }^{30,34,69,70,107,113}$ Although RCCs are considered nonneoplastic cystic lesions, recurrence rates following surgical intervention have been reported to be as high, or higher, than in some series following resection of CPs. ${ }^{2,16,26,54,71}$ More aggressive, or "transitional," subtypes of RCCs have been reported to comprise a significant proportion of these recurrences and are frequently characterized by less typical histopathological features (Fig. 5). A theory of acute and chronic inflammatory processes, perhaps incited by repeated cyst leakage or microhemorrhage, has been implicated in inciting the process of squamous metaplasia identified in some RCCs. ${ }^{33}$ Between 9 and $39 \%$ of RCCs demonstrate evidence of squamous metaplasia, which has been independently associated with higher rates of cyst recurrence. .,7,56,63,108 $^{\text {The }}$ higher recurrence rates observed in RCCs with squamous metaplasia support the idea that these are likely more aggressive lesions that more closely approach the natural history of $\mathrm{CP}^{2}$ The presence of stratified squamous epithelial cells in a minority of RCCs, as well as the higher MIB-1 labeling indexes associated with these lesions, also lends support to the theory that at least a subset of CPs may develop from such transitional intermediaries. ${ }^{41,69} \mathrm{~A}$ theory by Ikeda and Yoshimoto ${ }^{41}$ proposed that squamous epithelial cells in aggressive RCCs with higher proliferative indexes eventually outgrow and displace simple epithelium cell types.

More evidence for this hypothesis comes from reports of transitional-type pathology, consisting of histological features falling along different points of this histopathological continuum and occurring within the same lesion. ${ }^{34,87}$ In such cases, the intrasellar portion typically demonstrates features consistent with an RCC, whereas the suprasellar portion usually demonstrates features that are more typical for CP. Furthermore, numerous cases of ciliated epithelial cells or mucin-containing goblet cells occurring in squamous-papillary craniopharyngiomas have been reported and implicated as providing further support for a common ectodermal origin and transitional entity between RCCs and CPs. ${ }^{30,34,68,77,78}$ As these rare lesions' epithelial cells undergo transformation and no longer exhibit ciliation, it has been proposed that they develop into the more characteristic stratified squamous cell epithelial cells traditionally observed in the squamouspapillary subtype of $\mathrm{CP} .^{30,79}$

Finally, several cases of ciliated squamous-papillary CPs have been reported to arise directly from preexisting RCCs. ${ }^{79,82,93}$ In one of these studies, Park et al. ${ }^{82}$ reported a case of an RCC with negative $\beta$-catenin accumulation that transitioned into a $\mathrm{CP}$ with positive $\beta$-catenin accumulation. ${ }^{82} \mathrm{~A}$ major limitation of these reports, however, is that for any given case it cannot been proven with certainty that a CP neoplasm actually arose from a preexisting RCC. The possibilities of coexisting lesions or dif- 


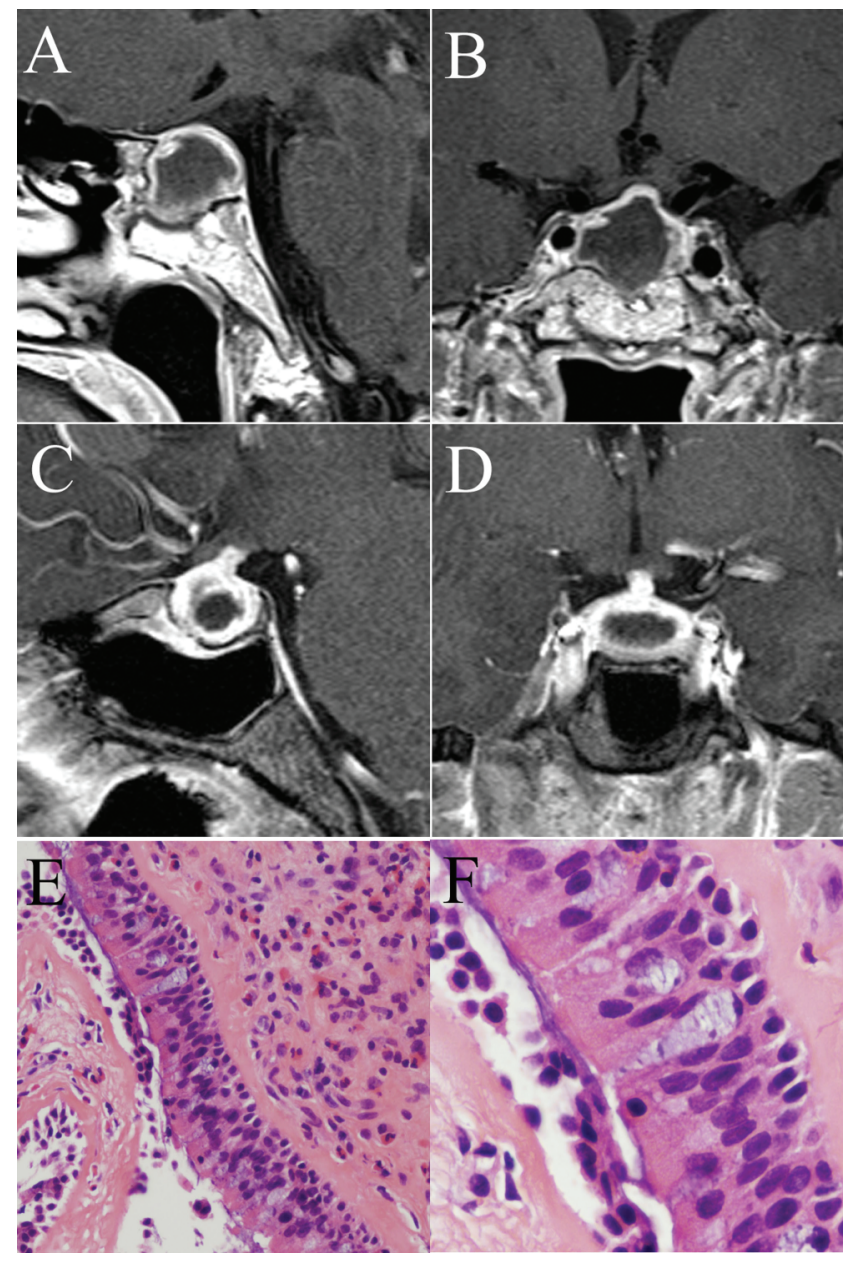

FIG. 5. Imaging and histopathological examples of atypical RCCs. A and B: Sagittal and coronal Gd-enhanced MR images acquired in a patient with a recurrent RCC and thickening of the cyst wall. $\quad \mathbf{C}$ and $\mathrm{D}$ : Sagittal and coronal Gd-enhanced MR images obtained in a patient with an RCC, demonstrating significant wall thickening and enhancement. E and F: Photomicrographs of an atypical RCC lined by columnar epithelium with frequent goblet cells and mucin production. $\mathrm{H}$ \& $\mathrm{E}$, original magnification $\times 100(E)$ and $400(F)$.

ferences in biopsy technique and tissue analysis can be alternative explanations for this phenomenon.

Another noteworthy histological category with features resembling those of both CPs and RCCs is the sellar xanthogranuloma. These lesions tend to occur in younger patients (mean 27 years), have a smaller diameter, and remain primarily intrasellar with infrequent calcification. ${ }^{83}$ Although they have been reported to comprise a distinct entity, it remains unknown whether they are derived from RCCs or CPs following extensive inflammation and metaplasia, to the point that no epithelium is readily identifiable. ${ }^{63,83}$ Le and coworkers ${ }^{63}$ reported that the features of xanthogranuloma were more consistent with RCCs than CPs and demonstrated a high association with squamous metaplasia of these lesions.

\section{Evidence Supporting Nonectodermal Origins of Cystic Epithelial Sellar Lesions}

In the past, some investigators have favored theories supporting nonectodermal origins of various cystic epithelial sellar lesions. One alternative explanation is a theory that RCCs and related epithelial sellar and parasellar cysts, including neurenteric cysts and colloid cysts, are derived from an endodermal origin..$^{32,43,44,81}$ The presence of histological features such as ciliation, goblet cells, and mucin associated with each of these lesions has provided the main argument in favor of this theory. ${ }^{42}$ As Harrison and colleagues ${ }^{34}$ described, however, similar histological findings can be identified in a variety of epithelial tumors located throughout the cerebrum. Furthermore, the same authors argued that the contents of the sella are purely ectodermal, with no valid explanation in place for how endodermal derivatives may arise here later during development, including theories of dysraphism. ${ }^{34}$ Another theory for the origin of cystic epithelial lesions in this region is that they are derived instead from neuroepithelial sources such as the neural crest, as supported by the finding of amyloid stroma in some examples. ${ }^{18,21,65,98}$ A third alternative theory suggests that cystic epithelial lesions are derived from metaplasia of anterior pituitary cells. ${ }^{3,39,95}$ Some authors have reported RCCs or CPs occurring in conjunction with pituitary adenomas as transitional or collision lesions. ${ }^{53,55}$ However, no evidence for a direct metaplastic origin of these cystic lesions from adenomas, or vice versa, has been proven as an alternative to a purely coincidental hypothesis. ${ }^{53}$

\section{Differentiation of Cystic CP and RCC}

Although RCCs and CPs may represent 2 poles of a pathological spectrum, they are for the most part distinct entities, and according to Thapar and Kovacs, ${ }^{101}$ have "differences that are much more compelling than are their similarities." Several previous reports have attempted to identify the clinical, radiological, and histopathological parameters that are most useful in accurately differentiating cystic sellar region pathology. In this section, these key characteristics are reviewed (Table 2).

\section{Clinical Features}

The majority of studies report overlapping clinical features for RCCs and CPs in adults, with regard to age distribution and sex. ${ }^{36}$ Similarly, presenting clinical features such as headache, endocrine deficits, visual deficits, and diabetes insipidus have not been reliably demonstrated to allow differentiation of CPs from RCCs. ${ }^{36,97}$ The only clinical features that have been reliably correlated with the diagnosis of $\mathrm{CP}$ over RCC, according to one study, were a significantly higher incidence of amenorrhea and neuropsychiatric deficits associated with $\mathrm{CP} .{ }^{97}$

\section{Imaging Features}

In many cases, imaging modalities can be used to more reliably differentiate RCCs from CPs and other cystic lesions. In some cases, this differentiation can be quite challenging, as the majority of studies have been unable to reliably do so based solely on T1- and T2-weighted intensity (Fig. 6). ${ }^{17,36,97}$ Calcification on CT imaging is often a useful characteristic for differentiat- 
G. Zada et al.

TABLE 2: Summary of clinical, imaging and histopathological characteristics that have been demonstrated to benefit in differentiating $\mathrm{CPs}$ and $\mathrm{RCCs}^{*}$

\begin{tabular}{|c|c|c|c|}
\hline \multirow[b]{2}{*}{ Feature } & \multicolumn{2}{|c|}{ All CPs } & \multirow[b]{2}{*}{ RCCs } \\
\hline & Adamantinomatous & Papillary & \\
\hline \multicolumn{4}{|l|}{ clinical } \\
\hline psychiatric deficits ${ }^{97}$ & + & + & - \\
\hline amenorrhea $^{97}$ & + & + & $+/-$ \\
\hline \multicolumn{4}{|l|}{ imaging } \\
\hline calcification $(\mathrm{CT})^{1,20,36,97}$ & ++ & - & - \\
\hline size $(>20 \mathrm{~mm})^{1,17,20,36,97}$ & + & + & $+/-$ \\
\hline \multicolumn{4}{|l|}{ location } \\
\hline suprasellar only ${ }^{17,36,97}$ & + & ++ & $+/-$ \\
\hline compressing 3rd ventricle $e^{17,97}$ & + & + & - \\
\hline ovoid shape ${ }^{17,97}$ & $+/-$ & + & ++ \\
\hline cyst wall enhancement ${ }^{17}$ & + & + & $+/-$ \\
\hline single-shot fast spin echo diffusion weighted imaging ${ }^{57}$ & + & + & - \\
\hline \multicolumn{4}{|l|}{ histopathology } \\
\hline calcification ${ }^{20,97}$ & + & - & - \\
\hline \multicolumn{4}{|l|}{ epithelial lining } \\
\hline adamantinomatous $\mathbf{s}^{1,33}$ & ++ & - & - \\
\hline squamous $^{36,56,97}$ & + & ++ & $+1-$ \\
\hline simple columnar ${ }^{36,97}$ & - & - & + \\
\hline simple cuboidal 36,97 & - & - & + \\
\hline pseudostratified columnar ${ }^{36,97}$ & - & - & + \\
\hline ciliated 36,97 & - & - & ++ \\
\hline mucinous/goblet cells $\mathbf{s}^{1,36,97}$ & - & + & ++ \\
\hline keratin nodules 36,97 & ++ & $+1-$ & - \\
\hline chronic inflammation ${ }^{56,97}$ & + & NA & $+/-$ \\
\hline \multicolumn{4}{|l|}{ markers } \\
\hline CK 863,111 & $+1-$ & $+/-$ & ++ \\
\hline CK 2063,111 & - & - & + \\
\hline nuclear $\beta$-catenin accumulation ${ }^{36}$ & ++ & - & - \\
\hline
\end{tabular}

* Superscripted numbers indicate studies discussing the respective feature. Abbreviations: NA = not applicable; ++ = quite common; + = more common; +/- = less likely; - = rare or absent.

ing RCCs from CPs. In previous studies, $42-87 \%$ of CPs exhibited calcification, compared with only $0-13 \%$ of RCCs. ${ }^{36,97}$ It is important to note, however, that several cases of RCCs have been reported to occur with ossification and no evidence of neoplastic features, and that the presence of calcium is not necessarily pathognomonic for CP. ${ }^{64,72}$

In 2006, Hofmann and colleagues ${ }^{36}$ reported that the imaging parameters that can be used to support a diagnosis of CP over RCC include: greater tumor diameter $(>2$ $\mathrm{cm}$ ), suprasellar location, and presence of calcification. In another study by Choi et al. ${ }^{17}$ MR imaging features were reviewed for RCCs, CPs, and cystic pituitary adenomas. Radiological parameters that supported a diagnosis of RCC were an ovoid shape, small cyst volume, and thin or no cyst wall enhancement. Conversely, a radiological di- agnosis of CP was supported by features such as superior tumor lobulation, larger tumor volume, compression of the third ventricle, and a reticular enhancement pattern of the solid tumor portion. Kunii et al. ${ }^{57}$ used single-shot fast spin echo diffusion weighted MR imaging to differentiate cystic sellar and suprasellar lesions. They reported that RCCs could be identified using this imaging modality because of the lesion's increased regional apparent diffusion coefficient values, in contrast with those of CPs and hemorrhagic pituitary adenomas. However, this modality was less useful in differentiating RCCs from cystic pituitary adenomas.

\section{Histopathological Features}

The most reliable methods of distinguishing cystic epithelial lesions are clearly based on histopathological 

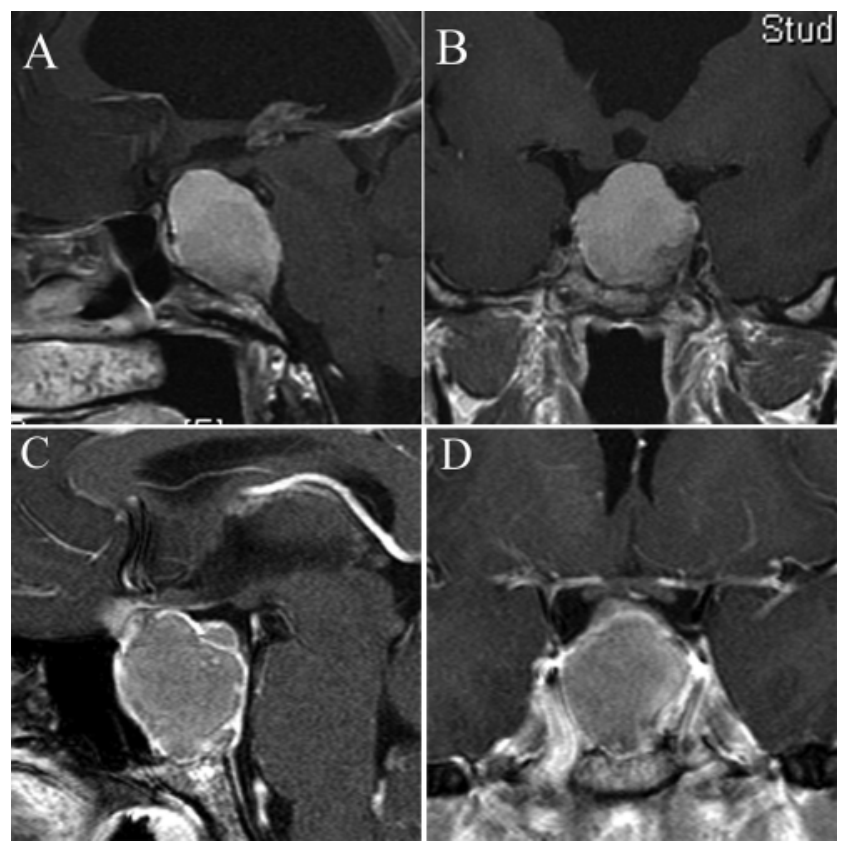

FIG. 6. Imaging examples demonstrating the potential difficulty in differentiating atypical CPs and RCCs. A and B: Sagittal and coronal Gd-enhanced MR images obtained in a patient with a recurrent RCC, demonstrating suprasellar, clival, and retrosellar extension. $\quad$ C and D: Sagittal and coronal Gd-enhanced MR images obtained in a patient with a cystic CP, also demonstrating suprasellar and infrasellar extension.

and molecular markers, representing the gold standard for diagnosis. However, even at a microscopic and molecular level the differentiation of these lesions is often not clear cut, which perhaps further elucidates why the clinical and radiological features are often indistinguishable.

In a report by Shin and associates, ${ }^{97}$ the histopathological features of RCCs and CPs were reviewed to identify those that correlated significantly with each lesion type. The authors determined that the characteristics correlating significantly with a diagnosis of RCC were simple columnar or cuboidal epithelium, pseudostratified columnar epithelium, and ciliation. Conversely, features supporting a diagnosis of CP included stratified squamous epithelium, calcification, keratin nodules, and chronic inflammation.

Nuclear immunohistochemical staining for $\beta$-catenin accumulation has been used as a reliable method of differentiation of some cystic sellar region lesions and has been shown to demonstrate immunoreactivity exclusively in CPs. ${ }^{36} \mathrm{~A}$ similar study demonstrated $\beta$-catenin immunoreactivity in $77 \%$ of CPs, particularly of the adamantinomatous subtype. ${ }^{13}$ Although useful, the downside of this modality is that it cannot be used to reliably differentiate squamous-papillary CPs from transitional RCCs, which is often the more formidable challenge. ${ }^{36}$

The expression patterns of various cytokeratins have also been reported to aid in the differentiation of RCCs from CPs yet with less consistency. In a study reviewing cytokeratin expression in 15 patients with cystic sellar lesions, Xin et al. ${ }^{111}$ reported that RCCs demonstrate expression of cytokeratins 8 and 20, whereas CP did not. Howev- er, a similar study in 2007 by Le and coworkers ${ }^{63}$ failed to demonstrate as reliable of a pattern, in which cytokeratin 8 reactivity occurred in all cases of RCC and $\mathrm{CP}$.

\section{Conclusions}

Varying subtypes of sellar and parasellar epithelial cystic masses may be difficult to differentiate on a clinical, imaging, or even histopathological basis. There is significant evidence to support a common ectodermal origin of such entities, which may account for the overlap of features and transitional states observed in some cases. The pattern of embryological formation of the hypothalamicpituitary axis plays a major role in its susceptibility to the development of such cystic epithelial lesions. Subsequent inflammatory, metaplastic and neoplastic processes may promote further progression along a pathological continuum ranging from benign epithelial cysts to aggressive neoplastic CPs. Research obtained from animal studies, reports of transitional cystic epithelial masses with nonspecific features, and reports of lesions crossing over from typical to more aggressive pathological subtypes have collectively provided a solid foundation for this idea. Selected clinical, imaging, and histopathological features can be used to aid in differentiating these lesions and assigning a formal diagnosis to guide further treatment.

\section{Acknowledgement}

The authors would like to thank Dr. Peter Chiarelli for assistance with journal collection.

\section{Disclosure}

The authors report no conflict of interest concerning the materials or methods used in this study or the findings specified in this paper.

Author contributions to the study and manuscript preparation include the following. Conception and design: G Zada, N Lin, ER Laws. Acquisition of data: G Zada, E Ojerholm, S Ramkissoon. Analysis and interpretation of data: GZada, S Ramkissoon, ER Laws. Drafting the article: G Zada, N Lin, E Ojerholm, S Ramkissoon, ER Laws. Critically revising the article: G Zada, N Lin, E Ojerholm, S Ramkissoon, ER Laws. Reviewed final version of the manuscript and approved it for submission: G Zada, N Lin, E Ojerholm, S Ramkissoon, ER Laws. Study supervision: ER Laws.

\section{References}

1. Adamson TE, Wiestler OD, Kleihues P, Yaşargil MG: Correlation of clinical and pathological features in surgically treated craniopharyngiomas. J Neurosurg 73:12-17, 1990

2. Aho CJ, Liu C, Zelman V, Couldwell WT, Weiss MH: Surgical outcomes in 118 patients with Rathke cleft cysts. J Neurosurg 102:189-193, 2005

3. Asa SL, Kovacs K, Bilbao JM: The pars tuberalis of the human pituitary. A histologic, immunohistochemical, ultrastructural and immunoelectron microscopic analysis. Virchows Arch A Pathol Anat Histopathol 399:49-59, 1983

4. Asari S, Ito T, Tsuchida S, Tsutsui T: MR appearance and cyst content of Rathke cleft cysts. J Comput Assist Tomogr 14:532-535, 1990

5. Babinski J: Tumeur du corps pituitaire sans acromegalie et avec arrêt développementdes organes génitaux. Rev Neurol 9:531-533, $1900(\mathrm{Fr})$

6. Barrow DL, Spector RH, Takei Y, Tindall GT: Symptomatic 
Rathke's cleft cysts located entirely in the suprasellar region: review of diagnosis, management, and pathogenesis. Neurosurgery 16:766-772, 1985

7. Benveniste RJ, King WA, Walsh J, Lee JS, Naidich TP, Post KD: Surgery for Rathke cleft cysts: technical considerations and outcomes. J Neurosurg 101:577-584, 2004

8. Binning MJ, Gottfried ON, Osborn AG, Couldwell WT: Rathke cleft cyst intracystic nodule: a characteristic magnetic resonance imaging finding. J Neurosurg 103:837-840, 2005

9. Boggan JE, Davis RL, Zorman G, Wilson CB: Intrasellar epidermoid cyst. Case report. J Neurosurg 58:411-415, 1983

10. Brassier G, Morandi X, Tayiar E, Riffaud L, Chabert E, Heresbach N, et al: Rathke's cleft cysts: surgical-MRI correlation in 16 symptomatic cases. J Neuroradiol 26:162-171, 1999

11. Brunel H, Raybaud C, Peretti-Viton P, Lena G, Girard N, PazParedes A, et al: [Craniopharyngioma in children: MRI study of 43 cases.] Neurochirurgie 48:309-318, 2002 (Fr)

12. Bunin GR, Surawicz TS, Witman PA, Preston-Martin S, Davis F, Bruner JM: The descriptive epidemiology of craniopharyngioma. J Neurosurg 89:547-551, 1998

13. Buslei R, Nolde M, Hofmann B, Meissner S, Eyupoglu IY, Siebzehnrübl F, et al: Common mutations of beta-catenin in adamantinomatous craniopharyngiomas but not in other tumours originating from the sellar region. Acta Neuropathol 109:589-597, 2005

14. Byun WM, Kim OL, Kim D: MR imaging findings of Rathke's cleft cysts: significance of intracystic nodules. AJNR Am J Neuroradiol 21:485-488, 2000

15. Cavallo LM, Prevedello D, Esposito F, Laws ER Jr, Dusick JR, Messina A, et al: The role of the endoscope in the transsphenoidal management of cystic lesions of the sellar region. Neurosurg Rev 31:55-64, 2008

16. Chakrabarti I, Amar AP, Couldwell W, Weiss MH: Longterm neurological, visual, and endocrine outcomes following transnasal resection of craniopharyngioma. J Neurosurg 102:650-657, 2005

17. Choi SH, Kwon BJ, Na DG, Kim JH, Han MH, Chang KH: Pituitary adenoma, craniopharyngioma, and Rathke cleft cyst involving both intrasellar and suprasellar regions: differentiation using MRI. Clin Radiol 62:453-462, 2007

18. Concha S, Hamilton BP, Millan JC, McQueen JD: Symptomatic Rathke's cleft cyst with amyloid stroma. J Neurol Neurosurg Psychiatry 38:782-786, 1975

19. Couldwell WT, Weiss MH: Nonadenomatous lesions of the pituitary, in Krisht A, Tindall, GT (eds): Pituitary Disorders. Baltimore, MD: Lipincott Williams \& Wilkins, 1999

20. Crotty TB, Scheithauer BW, Young WF Jr, Davis DH, Shaw EG, Miller GM, et al: Papillary craniopharyngioma: a clinicopathological study of 48 cases. J Neurosurg 83:206-214, 1995

21. Diengdoh JV, Scott T: Electron-microscopical study of a Rathke's cleft cyst. Acta Neuropathol 60:14-18, 1983

22. Eldevik OP, Blaivas M, Gabrielsen TO, Hald JK, Chandler WF: Craniopharyngioma: radiologic and histologic findings and recurrence. AJNR Am J Neuroradiol 17:1427-1439, 1996

23. Elliott RE, Wisoff JH: Successful surgical treatment of craniopharyngioma in very young children. J Neurosurg Pediatr 3:397-406, 2009

24. Erdheim J: Über Hypophysenganggeschwülste und Hirncholesteatome. Sitzungsber Kaiserliche Akad Wiss (Wien) 113 (sect3):537-726, 1904

25. Fager CA, Carter H: Intrasellar epithelial cysts. J Neurosurg 24:77-81, 1966

26. Fahlbusch R, Honegger J, Paulus W, Huk W, Buchfelder M: Surgical treatment of craniopharyngiomas: experience with 168 patients. J Neurosurg 90:237-250, 1999

27. Fatemi N, Dusick JR, de Paiva Neto MA, Kelly DF: The endo- nasal microscopic approach for pituitary adenomas and other parasellar tumors: a 10-year experience. Neurosurgery 63 (4 Suppl 2):244-256, 2008

28. Frohlich A: Ein Fall von Tumor der Hypophysis cerebri ohne Akromegalie. Wien Klin Rundschau 15:883-886, 903-906, 1901

29. Goldberg GM, Eshbaugh DE: Squamous cell nests of the pituitary gland as related to the origin of craniopharyngiomas. A study of their presence in the newborn and infants up to age four. Arch Pathol 70:293-299, 1960

30. Goodrich JT, Post KD, Duffy P: Ciliated craniopharyngioma. Surg Neurol 24:105-111, 1985

31. Gormley WB, Tomecek FJ, Qureshi N, Malik GM: Craniocerebral epidermoid and dermoid tumours: a review of 32 cases. Acta Neurochir (Wien) 128:115-121, 1994

32. Graziani N, Dufour H, Figarella-Branger D, Donnet A, Bouillot P, Grisoli F: Do the suprasellar neurenteric cyst, the Rathke cleft cyst and the colloid cyst constitute a same entity? Acta Neurochir (Wien) 133:174-180, 1995

33. Hama S, Arita K, Nishisaka T, Fukuhara T, Tominaga A, Sugiyama K, et al: Changes in the epithelium of Rathke cleft cyst associated with inflammation. J Neurosurg 96:209-216, 2002

34. Harrison MJ, Morgello S, Post KD: Epithelial cystic lesions of the sellar and parasellar region: a continuum of ectodermal derivatives? J Neurosurg 80:1018-1025, 1994

35. Hayashi Y, Tachibana O, Muramatsu N, Tsuchiya H, Tada M, Arakawa Y, et al: Rathke cleft cyst: MR and biomedical analysis of cyst content. J Comput Assist Tomogr 23:34-38, 1999

36. Hofmann BM, Kreutzer J, Saeger W, Buchfelder M, Blümcke I, Fahlbusch R, et al: Nuclear beta-catenin accumulation as reliable marker for the differentiation between cystic craniopharyngiomas and Rathke cleft cysts: a clinico-pathologic approach. Am J Surg Pathol 30:1595-1603, 2006

37. Honegger J, Barocka A, Sadri B, Fahlbusch R: Neuropsychological results of craniopharyngioma surgery in adults: a prospective study. Surg Neurol 50:19-29, 1998

38. Honegger J, Buchfelder M, Fahlbusch R: Surgical treatment of craniopharyngiomas: endocrinological results. J Neurosurg 90:251-257, 1999

39. Hunter IJ: Squamous metaplasia of cells of the anterior pituitary gland. J Pathol Bacteriol 69:141-145, 1955

40. Iaconetta G, Carvalho GA, Vorkapic P, Samii M: Intracerebral epidermoid tumor: a case report and review of the literature. Surg Neurol 55:218-222, 2001

41. Ikeda H, Yoshimoto T: Clinicopathological study of Rathke's cleft cysts. Clin Neuropathol 21:82-91, 2002

42. Ikeda H, Yoshimoto T, Suzuki J: Immunohistochemical study of Rathke's cleft cyst. Acta Neuropathol 77:33-38, 1988

43. Inoue T, Matsushima T, Fukui M, Iwaki T, Takeshita I, Kuromatsu C: Immunohistochemical study of intracranial cysts. Neurosurgery 23:576-581, 1988

44. Ishii T, Yamasaki T, Tanaka J, Tanaka S, Hori T, Muraoka K: [Rathke's cleft cyst-report of three cases.] No Shinkei Geka 15:451-456, 1987 (Japanese)

45. Isono M, Kamida T, Kobayashi H, Shimomura T, Matsuyama J: Clinical features of symptomatic Rathke's cleft cyst. Clin Neurol Neurosurg 103:96-100, 2001

46. Iwasaki K, Kondo A, Takahashi JB, Yamanobe K: Intraventricular craniopharyngioma: report of two cases and review of the literature. Surg Neurol 38:294-301, 1992

47. Iwata H, Hosoi M, Miyajima R, Yamamoto S, Mikami S, Yamakawa S, et al: Morphogenesis of craniopharyngeal derivatives in the neurohypophysis of Fisher 344 rats: abnormally developed epithelial tissues including parotid glands derived from the stomatodeum. Toxicol Pathol 28:568-574, 2000

48. Jagannathan J, Dumont AS, Jane JA Jr, Laws ER Jr: Pediatric 
sellar tumors: diagnostic procedures and management. Neurosurg Focus 18 (6A):E6, 2005

49. Jane JA Jr, Laws ER: Craniopharyngioma. Pituitary 9:323326,2006

50. Kanter AS, Sansur CA, Jane JA Jr, Laws ER Jr: Rathke's cleft cysts. Front Horm Res 34:127-157, 2006

51. Karavitaki N, Brufani C, Warner JT, Adams CB, Richards P, Ansorge $\mathrm{O}$, et al: Craniopharyngiomas in children and adults: systematic analysis of 121 cases with long-term follow-up. Clin Endocrinol (Oxf) 62:397-409, 2005

52. Karavitaki N, Cudlip S, Adams CB, Wass JA: Craniopharyngiomas. Endocr Rev 27:371-397, 2006

53. Karavitaki N, Scheithauer BW, Watt J, Ansorge O, Moschopoulos M, Llaguno AV, et al: Collision lesions of the sella: coexistence of craniopharyngioma with gonadotroph adenoma and of Rathke's cleft cyst with corticotroph adenoma. Pituitary 11:317-323, 2008

54. Kasperbauer JL, Orvidas LJ, Atkinson JL, Abboud CF: Rathke cleft cyst: diagnostic and therapeutic considerations. Laryngoscope 112:1836-1839, 2002

55. Kepes JJ: Transitional cell tumor of the pituitary gland developing from a Rathke's cleft cyst. Cancer 41:337-343, 1978

56. Kim JE, Kim JH, Kim OL, Paek SH, Kim DG, Chi JG, et al: Surgical treatment of symptomatic Rathke cleft cysts: clinical features and results with special attention to recurrence. J Neurosurg 100:33-40, 2004

57. Kunii N, Abe T, Kawamo M, Tanioka D, Izumiyama H, Moritani T: Rathke's cleft cysts: differentiation from other cystic lesions in the pituitary fossa by use of single-shot fast spin-echo diffusion-weighted MR imaging. Acta Neurochir (Wien) 149:759-769, 2007

58. Kurosaki M, Saeger W, Lüdecke DK: Immunohistochemical localisation of cytokeratins in craniopharyngioma. Acta Neurochir (Wien) 143:147-151, 2001

59. Laws ER: Craniopharyngiomas in children and young adults. Prog Exp Tumor Res 30:335-340, 1987

60. Laws ER: Endoscopic surgery for cystic lesions of the pituitary region. Nat Clin Pract Endocrinol Metab 4:662-663, 2008

61. Laws ER, Kanter AS: Rathke cleft cysts. J Neurosurg 101:571-572, 2004

62. Laws ER, Weiss MH, White WL: Craniopharyngioma. Skull Base 13:55-58, 2003

63. Le BH, Towfighi J, Kapadia SB, Lopes MB: Comparative immunohistochemical assessment of craniopharyngioma and related lesions. Endocr Pathol 18:23-30, 2007

64. Lee CH, Seo EK, Cho YJ, Kim SJ: Large ossified Rathke's cleft cyst - a case report and review of the literature. J Korean Neurosurg Soc 44:256-258, 2008

65. Leech RW, Olafson RA: Epithelial cysts of the neuraxis: presentation of three cases and a review of the origins and classification. Arch Pathol Lab Med 101:196-202, 1977

66. Luschka Hv: Der Hirnanhang u.d. Steissdruse d. Menschen. Berlin, 1860

67. Maartens N, Kaye A: Transsphenoidal resection of craniopharyngiomas, in Laws ER, Lanzino G (eds): Transsphenoidal Surgery. Philadelphia: Elsevier, 2006

68. Maruki C, Shimoji T, Kijima H, Matsumoto M, Maeda M: Ciliated epithelial cell cluster in Rathke's cleft cyst-report of two cases. Neurol Med Chir (Tokyo) 31:92-95, 1991

69. Matsushima T, Fukui M, Fujii K, Kinoshita K, Yamakawa Y: Epithelial cells in symptomatic Rathke's cleft cysts. A light- and electron-microscopic study. Surg Neurol 30:197-203, 1988

70. Matsushima T, Fukui M, Ohta M, Yamakawa Y, Takaki T, Okano H: Ciliated and goblet cells in craniopharyngioma. Light and electron microscopic studies at surgery and autopsy. Acta Neuropathol 50:199-205, 1980

71. Mukherjee JJ, Islam N, Kaltsas G, Lowe DG, Charlesworth M, Afshar F, et al: Clinical, radiological and pathological features of patients with Rathke's cleft cysts: tumors that may recur. J Clin Endocrinol Metab 82:2357-2362, 1997

72. Nakasu Y, Nakasu S, Nakajima M, Itoh R, Matsuda M: Atypical Rathke's cleft cyst associated with ossification. AJNR Am J Neuroradiol 20:1287-1289, 1999

73. Nemergut EC, Zuo Z, Jane JA Jr, Laws ER Jr: Predictors of diabetes insipidus after transsphenoidal surgery: a review of 881 patients. J Neurosurg 103:448-454, 2005

74. Netsky MG: Epidermoid tumors. Review of the literature. Surg Neurol 29:477-483, 1988

75. Nishioka H, Haraoka J, Izawa H, Ikeda Y: Magnetic resonance imaging, clinical manifestations, and management of Rathke's cleft cyst. Clin Endocrinol (Oxf) 64:184-188, 2006

76. Oge K, Ozgen T: Transsphenoidal removal of an intra- and suprasellar epidermoid cyst. Neurochirurgia (Stuttg) 34:9496, 1991

77. Oka H, Kawano N, Yagishita S, Kobayashi I, Saegusa H, Fujii K: Ciliated craniopharyngioma indicates histogenetic relationship to Rathke cleft epithelium. Clin Neuropathol 16:103-106, 1997

78. Oka H, Kawano N, Yagishita S, Suwa T, Yoshida T, Maezawa $\mathrm{H}$, et al: Origin of ciliated craniopharyngioma: pathological relationship between Rathke cleft cyst and ciliated craniopharyngioma. Noshuyo Byori 12:97-103, 1995

79. Okada T, Fujitsu K, Miyahara K, Ichikawa T, Takemoto Y, Niino H, et al: Ciliated craniopharyngioma-case report and pathological study. Acta Neurochir (Wien) 152:303-307, 2010

80. Oskouian RJ, Samii A, Laws ER Jr: The craniopharyngioma. Front Horm Res 34:105-126, 2006

81. Palma L, Celli P: Suprasellar epithelial cyst. Case report. J Neurosurg 58:763-765, 1983

82. Park YS, Ahn JY, Kim DS, Kim TS, Kim SH: Late development of craniopharyngioma following surgery for Rathke's cleft cyst. Clin Neuropathol 28:177-181, 2009

83. Paulus W, Honegger J, Keyvani K, Fahlbusch R: Xanthogranuloma of the sellar region: a clinicopathological entity different from adamantinomatous craniopharyngioma. Acta Neuropathol 97:377-382, 1999

84. Prabhu VC, Brown HG: The pathogenesis of craniopharyngiomas. Childs Nerv Syst 21:622-627, 2005

85. Rathke H: Ueber die Entstehung der Glandula pituitaria. Arch Anat Physiol Wiss Med 5:482-485, 1838

86. Ross DA, Norman D, Wilson CB: Radiologic characteristics and results of surgical management of Rathke's cysts in 43 patients. Neurosurgery 30:173-179, 1992

87. Russell D, Rubinstein L: Pathology of Tumours of the Nervous System, ed 5: Williams \& Wilkins, 1989

88. Sadler T: Langman's Medical Embryology. Philadelphia: Lippincott Williams \& Wilkins, 2009, p 414

89. Saeger W, Lüdecke DK, Buchfelder M, Fahlbusch R, Quabbe HJ, Petersenn S: Pathohistological classification of pituitary tumors: 10 years of experience with the German Pituitary Tumor Registry. Eur J Endocrinol 156:203-216, 2007

90. Saeki N, Sunami K, Sugaya Y, Yamaura A: MRI findings and clinical manifestations in Rathke's cleft cyst. Acta Neurochir (Wien) 141:1055-1061, 1999

91. Sani S, Smith A, Leppla DC, Ilangovan S, Glick R: Epidermoid cyst of the sphenoid sinus with extension into the sella turcica presenting as pituitary apoplexy: case report. Surg Neurol 63:394-397, 2005

92. Sartoretti-Schefer S, Wichmann W, Aguzzi A, Valavanis A: MR differentiation of adamantinous and squamous-papillary craniopharyngiomas. AJNR Am J Neuroradiol 18:77-87, 1997

93. Sato K, Oka H, Utsuki S, Kondo K, Kurata A, Fujii K: Ciliated craniopharyngioma may arise from Rathke cleft cyst. Clin Neuropathol 25:25-28, 2006

94. Schaetti P, Argentino-Storino A, Heinrichs M, Mirea D, Popp A, 


\section{G. Zada et al.}

Karbe E: Aberrant craniopharyngeal structures within the neurohypophysis of rats. Exp Toxicol Pathol 47:129-137, 1995

95. Shanklin WM: The histogenesis and histology of an integumentary type of epithelium in the human hypophysis. Anat Rec 109:217-231, 1951

96. Shimoji T, Shinohara A, Shimizu A, Sato K, Ishii S: Rathke cleft cysts. Surg Neurol 21:295-310, 1984

97. Shin JL, Asa SL, Woodhouse LJ, Smyth HS, Ezzat S: Cystic lesions of the pituitary: clinicopathological features distinguishing craniopharyngioma, Rathke's cleft cyst, and arachnoid cyst. J Clin Endocrinol Metab 84:3972-3982, 1999

98. Shuangshoti S, Netsky MG, Nashold BS Jr: Epithelial cysts related to sella turcica. Proposed origin from neuroepithelium. Arch Pathol 90:444-450, 1970

99. Tatagiba M, Iaconetta G, Samii M: Epidermoid cyst of the cavernous sinus: clinical features, pathogenesis and treatment. Br J Neurosurg 14:571-575, 2000

100. Teramoto A, Hirakawa K, Sanno N, Osamura Y: Incidental pituitary lesions in 1,000 unselected autopsy specimens. Radiology 193:161-164, 1994

101. Thapar K, Kovacs K: Cystic lesions of the sellar region, in Bigner D, McLendon R, Bruner J (eds): Russell and Rubinsteins's Pathology of Tumors of the Central Nervous System, ed 6. New York: Oxford University Press, 1998, Vol 2, pp 650-652

102. Tominaga JY, Higano S, Takahashi S: Characteristics of Rathke's cleft cyst in MR imaging. Magn Reson Med Sci 2:1-8, 2003

103. Tsuruda JS, Chew WM, Moseley ME, Norman D: Diffusionweighted MR imaging of the brain: value of differentiating between extraaxial cysts and epidermoid tumors. AJR Am J Roentgenol 155:1059-1068, 1990

104. Tuna H, Torun F, Torun AN, Erdogan A: Intrasellar epidermoid cyst presenting as pituitary apoplexy. J Clin Neurosci 15:1154-1156, 2008

105. Van Effenterre R, Boch AL: Craniopharyngioma in adults and children: a study of 122 surgical cases. J Neurosurg 97:3-11, 2002

106. VanGilder JC, Inukai J: Growth characteristics of experimental intracerebrally transplanted oral epithelium. J Neurosurg 38:608-615, 1973

107. Verkijk A, Bots GT: An intrasellar cyst with both Rathke's cleft and epidermoid characteristics. Acta Neurochir (Wien) 51:203-207, 1980

108. Voelker JL, Campbell RL, Muller J: Clinical, radiographic, and pathological features of symptomatic Rathke's cleft cysts. J Neurosurg 74:535-544, 1991

109. Weiner HL, Wisoff JH, Rosenberg ME, Kupersmith MJ, Cohen $\mathrm{H}$, Zagzag D, et al: Craniopharyngiomas: a clinicopathological analysis of factors predictive of recurrence and functional outcome. Neurosurgery 35:1001-1011, 1994

110. Wenger M, Simko M, Markwalder R, Taub E: An entirely suprasellar Rathke's cleft cyst: case report and review of the literature. J Clin Neurosci 8:564-567, 2001

111. Xin W, Rubin MA, McKeever PE: Differential expression of cytokeratins 8 and 20 distinguishes craniopharyngioma from Rathke cleft cyst. Arch Pathol Lab Med 126:1174-1178, 2002

112. Yaşargil MG, Abernathey CD, Sarioglu AC: Microneurosurgical treatment of intracranial dermoid and epidermoid tumors. Neurosurgery 24:561-567, 1989

113. Yoshida J, Kobayashi T, Kageyama N, Kanzaki M: Symptomatic Rathke's cleft cyst. Morphological study with light and electron microscopy and tissue culture. J Neurosurg 47:451-458, 1977

114. Zada G, Ditty B, McNatt SA, McComb JG, Krieger MD: Surgical treatment of Rathke cleft cysts in children. Neurosurgery 64:1132-1038, 2009

115. Zada G, Kelly DF, Cohan P, Wang C, Swerdloff R: Endonasal transsphenoidal approach for pituitary adenomas and other sellar lesions: an assessment of efficacy, safety, and patient impressions. J Neurosurg 98:350-358, 2003

116. Zada G, Liu CY, Fishback D, Singer PA, Weiss MH: Recognition and management of delayed hyponatremia following transsphenoidal pituitary surgery. J Neurosurg 106:66-71, 2007

Manuscript submitted December 15, 2009.

Accepted February 23, 2010.

Address correspondence to: Gabriel Zada, M.D., Department of Neurosurgery, Brigham and Women's Hospital, 15 Francis Street, PBB3, Boston, Massachusetts 02115. email:gzada@usc.edu. 